\title{
The Impact of Customer Relationship Management on Long-term Customers' Loyalty in the Palestinian Banking Industry
}

\author{
Raed A. M. Iriqat ${ }^{1} \&$ Mohannad A. M. Abu Daqar ${ }^{2}$ \\ ${ }^{1}$ Business Administration Department, Faculty of Administrative and Financial Sciences, Arab American \\ University \\ ${ }^{2}$ Master student, Faculty of Graduate Studies, Arab American University \\ Correspondence: Raed Ali Mahmoud Iriqat, Business Administration Department, Faculty of Administrative and \\ Financial Sciences. Arab American University, P. O. BOX 240, Jenin-West Bank, Palestine.
}

Received: September 15, 2017

Accepted: October 11, $2017 \quad$ Online Published: October 13, 2017

doi:10.5539/ibr.v10n11p139

URL: https://doi.org/10.5539/ibr.v10n11p139

\begin{abstract}
This paper aims to investigate the impact of customer relationship management on Long-term Customers' Loyalty in the Palestinian banking industry. The data was collected through distributing questionnaires on the Palestinian banking employees. Using multiple regression analysis tests, this paper finds these results; there is a positive and strong linear relationship between dependent variable "long-term customers' loyalty" and CRM, the CRM dimensions are service quality, customer's database, solving customer's problems, employees behavior, and CRM system integration. At the end, the two predictors (employee's behavior and CRM system integration) explained $48.2 \%$ of the variance in the long-term customers' loyalty. The scholars' found that banks have to investigate why there is a difference in the service quality level between male and female employees where male employees more effective than females. Furthermore, banks need to update their customers' database in order to be alerted to changes in their customers' requirements and needs to retain their loyal relationships with customers.
\end{abstract}

Keywords: CRM, Customer relationship management, long-term customers' loyalty, service quality, customer's database, solving customer's problems, employees behavior and CRM system integration

\section{Introduction}

The Palestinian banking industry has a significant role in the local development by providing the financial support in order to help the citizens to establish new businesses and provide them with the financial aid to let them cope with financial risks related to the unstable situation in Palestine, and on the other side, it helps them to ensure a secure a fund source to grant them with the required liquidity. Banks compete in the Palestinian local market to provide the proper borrowing facilities and procedures that are aligned with the customers' needs and expectation because in there are many cases citizens' have lack of requirements and guarantees to earn the required financial aid. So the Banks undertake these procedures in order to build a strong relationship with its customers to satisfy their needs and keep satisfying them in the long run to create a loyal customers' segment. In this regard, this paper aims to investigate the impact of managing customers' relationship with the banks to achieve their loyalty (Mosallem, n.d.).

Business owners often concentrate on the improvement of their products and services, this is one of the basic features of the production concept. Often, they neglect their customer care and relationship; as a result, many of their customers move their purchasing decisions to organizations who can serve them better. The problem here is that they fail to understand that customers' value, care, and concern is far above the product quality. So, companies tend to try their best as much as possible to satisfy their customers and even attract more besides to strengthening loyalty (Long, Khalafinezhad \& Wan Ismail, 2013).

Customer relationship management (CRM) refers to practices, strategies, technologies and a marketing tool that the banks in Palestine use to manage and analyze their customer's interactions and data throughout the customer lifecycle. The goal of improving the banks business relationships with customers is to assist in customer's retention and driving sales growth (Rouse, 2014).

Customer profitability systems can be the most powerful basis for a CRM implementation. Successful CRM 
programs increased customer loyalty. They have in plentiful instances even increased company revenues (Salawdeh, 2009). Banks in Palestine need to use effective CRM application, that enables them to easily gather critical sales and marketing information, not only pays for itself very quickly, it becomes a valuable resource for improving both the top revenue and the bottom profit lines.

Ranade (2012) shows that loyalty defined as a customer continuing to believe that the organization's product/service offer is his best option. It fulfills their value proposition whatever that may be. They take that offer whenever faced with that purchasing decision. Banks in Palestine competing in the local market to capture a better market share among this massive competition, the aim of these banks is to build a strong relationship with its customers for a better long-term loyalty with them.

The total number of the operated banks in Palestine is 15 banks, divided into local and foreign banks, foreign banks are the majority ( 8 foreign, 7 local). Around 7,000 employees working in these banks in Palestine (PMO, 2017). Banks in Palestine using CRM as a tool for managing the company's interactions with customers, users and all sales and financial issues. It uses technology to facilitate and manage the business processes and activities. Thus, CRM is an issue of strategic business and process rather than a technical one (Dowling, 2002).

The ultimate objective of this paper is to discover the impact of customer relationship management on long-term customers' loyalty in the Palestinian banking industry. And also, to highlight the most effective CRM dimensions that decision makers use to build and improve their CRM applications to help them in building a loyal relationship with customers. This study consisted of five parts, the introduction, the second part is the literature review which presents the theoretical and the empirical reviews for the previous studies about the study topic, methodology is the third part that contains data collection, validity, and reliability of questionnaire, conceptual model, the population and sample size, and the data analysis method used in this thesis. Whereas part four reflects the data analyses that are correspondent to the testing hypothesis and the results discussion, the last part is the scholars' conclusion.

\section{Literature Review}

The literature review in this study investigates the impact of customer relationship management on long-term customers' loyalty in the Palestinian banking industry. Literature review separated into two parts, theoretical and empirical literature reviews.

\subsection{Theoretical Literature Review}

Customer relationship management is a relatively new concept which emerged in the 1980s; with Saarijärvi et al. (2013b) noting that the early versions of CRM were referred to as database marketing and mainly consisted of interactions between customers and organizational staff. Stein et al. (2013) and Nguyen and Mutum (2012b) detail the rise of CRM as organizations started leveraging the benefits of collecting customer information in order to better satisfy their customers and enhance customer retention. Nguyen and Mutum (2012b) also note that during the 90s, more organizations considered customer service as a skill under continuous evolution that needed further investments. Goddard et al. (2012) claim that CRM has achieved the potential first seen in the 1980 s, enabling organizations to enhance customer service by customizing their product and service offerings to specific customer segments and improving customer retention.

Customer relationship management has emerged as a crucial strategy for: (1) identification of profitable banking prospects and customers, while also (2) enabling banks to devote attention and time to enhancing account relationships with such clients via customized services, (3) discretionary decision-making, (4) re-pricing, and (5) marketing (Farquad et al., 2012; Vella et al., 2012; Awasthi \& Sangle, 2013). Furthermore, Agariya and Singh (2012) add that CRM aids banks in differentiating customer segments according to profitability and business; as well as identifying associated risks with loan applicants, customers most likely to leave the bank, respond to offers, and default on their credit.

Despite the rapid growing CRM literature, the CRM dimensions and their effects on the customer outcomes need more studies for more results. Hollensen (2015) and Kumar and Reinartz (2012) identify two fundamental dimensions of CRM, which are (1) the human dimension and (2) the business dimension; in which the human dimension entails the recognition and response to the human needs of the customer, as well as the incorporation of gratitude and courtesy into customer service. In this case, acknowledging the concerns of the clients and defusing issues helps to enhance customer retention. Muther (2012) and Karjaluoto et al. (2014) expound further on five other dimensions which are service quality, customer's database, solving problems, employee behavior, and CRM system integration that entail the identification and satisfaction of business needs and the balancing of the organization's need for profitable operations and the customer's needs for quality service and products. In this 
paper, the scholars' focuses on five key CRM dimensions that other researchers found in many industries that these dimensions significantly enhance customers' loyalty, service quality, customer's database, solving customer's problems, employees' behavior and CRM system integration.

Customers' loyal ty refers to an organization's success in creating and maintaining a long-term relationship with clients (Lawfer, 2014; Evanschitzky et al., 2012). In this case, one of the most important objectives of a business is to ensure that customers engage in continued, preferably profitable, business with the organization. Further, Burke (2015), and Sachs (2013) define Long-term Customer Loyalty as a relationship in which customers provide repeat business to one organization because of a certain feature in the latter's product or service despite having other options. Lowenstein (2014) provides the definition of Long-term Customers' Loyalty from the perspective of brands, stating that loyalty is the commitment by customers to repurchase a product or service and further advocate for the product through word of mouth. Martinez and Del Bosque (2013) also define of Long-term Customers' Loyalty from the perspective of repurchase behavior, but further, argue that it is the customer's high relative attitude to a specific organization or brand.

There are several dimensions of long-term customers' loyalty, including (1) effective and (2) logical commitment (Kitapci et al., 2013), (3) decreased loyalty to competitors (Lawfer, 2014; Burke, 2015; Martinez \& Del Bosque, 2013), and (4) repurchase (Beneke et al., 2012; Sachs, 2013). Other dimensions of loyalty include (5) positive word of mouth (Lowenstein, 2014) and (6) purchase of other services or products from the organization (Evanschitzky et al., 2012).

\subsection{Empirical Literature Review}

In this section, the scholars' in this research will discuss the empirical reviews for CRM and long-term customer's loyalty.

\section{Customer Relationship Management}

Meadows and Dibb (2012), noting that the implementation of CRM can be problematic despite its widespread use in the management of client data, set out to investigate progress in the adoption of customer relationship management across different sectors in the services industry. The researchers used a CRM framework to explore the implementation progress of CRM with regard to the company, the staff, clients, and available CRM-enabling technology. The thesis determined several important variations in CRM implementation in different sectors, finding that CRM was particularly present in the banking sector.

Saarijärvi et al. (2013a) also set out to investigate the current status of customer relationships management in the service industry, in this case with regard to CRM's role in empowering customers and organizations. Noting the lack of adequate investigation of this issue in current literature, the researchers, however, argue for the need to shift CRM's focus towards the empowerment of clients and away from the over-focus on empowering the organization. Thus, this thesis shows that data collected through CRM should be used for the client' benefit specifically to deepen and lengthen the relationship.

Nguyen and Mutum (2012a), on the other hand, sought to characterize the advances, successes, pitfalls, and futures of customer relationships management. According to their findings, there is a significant risk that the customer's trust perceptions could be depleted if they perceive that the CRM offerings by the organization are merely exploiting the hem as customers. As a result, CRM should be implemented and practiced in a manner that benefits the customer as well as the organization by incorporating issues of trust, honesty, and fairness.

\section{Long-term Customers' Loyalty}

Due to the importance of customer loyalty to organizational performance and sustainability, there is a broad selection of literature about this concept and its relationship with various constructs of customer gratification and CRM. Pan et al. (2012) conducted an empirical investigation on the antecedents and predictors of customer loyalty and hypothesized that trust, which is a potential outcome of customer satisfaction, had a stronger effect size as a determinant of long-term loyalty. The findings show that product performance in terms of quality and gratification had a smaller effect size on Long-term Customers' Loyalty compared to trust and relationship quality.

Amin et al. (2012) examined the factors that contribute to customer loyalty in the service industry by administering a questionnaire survey to uni versity students. From the findings, a positive relationship emerged between customer loyalty on one side and perceived service quality, corporate image, trust, and switching cost on the other. The results also implied that service quality perceptions by the customer entailed the most significant determinant of customer loyalty, particularly in long-term relationships. 
Hassan et al. (2012) empirically measured customer loyalty among clients of Islamic banking, with the aim of determining their long-term commitment. Using data from questionnaire surveys administered to 125 customers from 20 Islamic banking financial institutions, the authors found that switching costs, customer satisfaction, customer perception, trust, and success philosophy had the significant influence on Islamic banking-customer loyalty. These findings indicate that financial institutions offering Islamic banking services should improve service quality, as well as create more awareness about the quality of these services, to enhance the loyalty of their customers.

\section{Hypotheses}

The First Null Hypothesis: There is no significant relationship between CRM and Long-term Customers' Loyalty in the Palestinian Banking Industry.

The First Alternative Hypothesis: There is a significant relationship between CRM and Long-term Customers' Loyalty in the Palestinian Banking Industry.

The Second Null Hypothesis: There is no significant impact of CRM dimensions on Long-term Customers' Loyalty in the Palestinian Banking Industry.

The Second Alternative Hypothesis: There is a significant impact of CRM dimensions on Long-term Customers' Loyalty in the Palestinian Banking Industry.

\section{Methodology}

\subsection{Data Collection and Reliability}

The scholars' used the primary data in this paper. The survey questionnaire is used to gather data from bankers in the operated banks in Palestine. This questionnaire consisted of three sections, section one is CRM which is developed by Hashem et al (2012), in this section it has five sub-sections, 1) service quality is structured into 13 items, 2) customer's database has 7 items, 3) employee's behavior 6 items, 4) solving customer's problem 12 items and 5) CRM system integration has 7 items. Section 2 is long-term customers' loyalty developed by Harsandaldeep Kaur and Harmeen Soch (2012) which has 11 items and the last part consisted of general and demographic information about the respondents which has seven variables, the overall items in the first three sections is 56. It is a five Likert scale questionnaire except for the third section from 5= Strongly Agree, $1=$ Strongly Disagree.

Reliability in this paper is calculated by using Cronbach's Alpha equations. It was (0.951) for the first dimension (CRM), (0.842) for the second dimension (Long-term Customer's Loyalty), in and the total of the questionnaire effectiveness was (0.897).

\subsection{Population and Sample size}

Banks in Palestine employ more than 7,000 persons. The population of this paper is limited to the employees of the local and foreign banks in North West Bank (around 1,960 employees). The scholars' used Krejcie and Morgan (1970) equation to determine the sample size, so the minimum number of sample size is 322 bankers in the operated banks in Palestine. The scholars' used a simple random sample that is suitable for the study objectives.

\subsection{Conceptual Model}

The overall objective of this paper is to find out the impact of CRM dimensions on long-term customers' loyalty in the Palestinian Banking Industry. Banks must improve its relationship with customers which help them to deliver services and products beyond customer expectations in order to retain their existing customers (Winer, 2001). The conceptual framework for this paper is developed on this framework which is the effective CRM dimensions is a key ingredient for long-term customers' loyalty. Table 1 shows the study variables and its related indicators. Therefore, the scholars' in this paper set the conceptual framework to guide this study as the follows in figure 1.

Table 1. Study Variables and its related indicators

\begin{tabular}{lll}
\hline Variables & Type & Related indicators \\
\hline CRM (Customer Relationship Management) & Independent & Solving problems \\
& & Customers DB \\
& & Service quality \\
& & Employee behavior \\
Long-term customers' loyalty & & CRM system integration \\
\hline
\end{tabular}






Figure 1. Conceptual Model

\section{Data Anal ysis}

\subsection{Testing Hypotheses}

The data were analyzed by using the statistical package for Social Sciences (SPSS) version 23. The data were checked for entry errors. The relationship between variables was analyzed by the using Pearson correlation, multilinear regression to test the significant impact of CRM dimensions on long-term customers loyalty.

H0-1: There is no significant relationship between CRM and Long-term Customers' Loyalty in the Palestinian Banking Industry

Ha-1: There is a significant relationship between CRM and Long-term Customers' Loyalty in the Palestinian Banking Industry

Table 2. Correlation coefficients among CRM and Long-term Customers' Loyalty variables

\begin{tabular}{lccccccc}
\hline Dimensions & 1 & 2 & 3 & 4 & 5 & 6 & 7 \\
\hline Service Quality & 1 & 1 & & & & & \\
Customers Database & $.683^{* *}$ & 1 & & & & \\
Employees Behavior & $.520^{* *}$ & $.541^{* *}$ & 1 & & & \\
Solving Customers Problems & $.725^{* *}$ & $.622^{* *}$ & $.625^{* *}$ & 1 & & \\
CRM System Integration & $.481^{* *}$ & $.539^{* *}$ & $.358^{* *}$ & $.649^{* *}$ & 1 & \\
CRM & $.873^{* *}$ & $.819^{* *}$ & $.734^{* *}$ & $.901^{* *}$ & $.723^{* *}$ & 1 \\
Long-term Customers' Loyalty & $.327^{* *}$ & $.292^{* *}$ & $.253^{* *}$ & $.415^{* *}$ & $.577^{* *}$ & $.451^{* *}$ & 1 \\
\hline
\end{tabular}

**. Correlation is significant at the 0.01 level

Source: Researcher

The size of the value of the correlation coefficient was decided, for indicating the relationship strength between two variables. According to Cohen's standard (1962), the guidelines for assessing the relationship are showing in Table 3. 
Table 3. The guidelines for assessing the relationship

\begin{tabular}{cc}
\hline Strength & Value \\
\hline Small & 0.10 to 0.29 \\
Medium & 0.30 to 0.49 \\
Large & 0.50 to 1.0 \\
\hline
\end{tabular}

Source: (Cohen, 1988)

As shown in table 2, the relationships between all independent and dependent variables are seen positive. Here the scholars' can see that, 1) In Palestine banking industry, Service Quality significantly related to CRM. Although the Solving Customers Problems could offer more attractive terms, the consumers in Palestine do not tend to switch their banks; 2) CRM System Integration is a better predictor than Employees Behavior of Long-term Customers' Loyalty, as its higher correlation of 0.577 than 0.292 .

Based on the scale in the above table 3, the scholars' can conclude from Table 2 that: Service Quality hasn't the strongest relationship with the formation of Long-term Customers' Loyalty, less than the role of CRM System Integration; oppositely, the Employees Behavior has minor impact on the loyalty, less than the influence of Service Quality.

H0-2: There is no significant impact of CRM dimensions on Long-term Customers' Loyalty in the Palestinian Banking Industry

Ha-2: There is a significant impact of CRM dimensions on Long-term Customers' Loyalty in the Palestinian Banking Industry

Table 4. R-square and ANOVA for econometrics model

\begin{tabular}{|c|c|c|c|c|c|c|c|c|}
\hline Model & $\begin{array}{c}\text { Sum of } \\
\text { Squares }\end{array}$ & df & $\begin{array}{c}\text { Mean } \\
\text { Square }\end{array}$ & $\mathrm{F}$ & Sig. & $\mathrm{R}$ & R Square & $\begin{array}{c}\text { Adjusted R } \\
\text { Square }\end{array}$ \\
\hline Regression & 14.506 & 5 & 2.901 & 26.020 & $.000^{\mathrm{b}}$ & & & \\
\hline Residual & 15.610 & 223 & .111 & & & $.694^{\mathrm{a}}$ & .482 & .463 \\
\hline Total & 30.115 & 228 & & & & & & \\
\hline
\end{tabular}

a. Dependent Variable: Long-term Customers Loyalty

Source: Researchers

The scholars' results from table 4, using ANOVA, it also shows a significant value of 26.02 for the F distribution with 5 and $223 \mathrm{df}$. The F-test can be taken as a measure of overall model significance of the estimated regression, indicates that the p-value is less than 0.05 , which implies that a significant relationship exists between the selected variables in this model in other words "Indicates that the combination of these variables significantly predicts the dependent variable", also as $\mathrm{R}^{2}=0.482$ which means the independents variables explain $48.2 \%$ from the variation of dependent variable "long-term customers' loyalty", also Multiple correlation coefficients " $\mathrm{r}=0.694$ " shows positive and strong linear relationship between dependent variable "Long-term Customers Loyalty" and the predictors.

Table 5. The OLS summary statistics of the null hypothesis

\begin{tabular}{|c|c|c|c|c|c|}
\hline \multirow[b]{2}{*}{ Model } & \multicolumn{2}{|c|}{ Unstandardized Coefficients } & $\begin{array}{l}\text { Standardized } \\
\text { Coefficients }\end{array}$ & \multirow[b]{2}{*}{$\mathrm{t}$} & \multirow[b]{2}{*}{ Sig. } \\
\hline & $\mathrm{B}$ & Std. Error & Beta & & \\
\hline (Constant) & -.246 & .543 & & -.454 & .650 \\
\hline Service Quality & .048 & .071 & .042 & .680 & .497 \\
\hline Customers Database & .075 & .119 & .058 & .635 & .526 \\
\hline Employees Behavior & .274 & .105 & .251 & 2.610 & .010 \\
\hline Solving Customers Problems & .006 & .122 & .005 & .053 & .958 \\
\hline CRM System Integration & .618 & .058 & .650 & 10.618 & .000 \\
\hline
\end{tabular}

Source: Researchers

Multiple regression analysis was used to test if CRM dimensions significantly predicted Long-term Customers' Loyalty. The results of the regression indicated the two predictors (Employees Behavior and CRM System Integration) explained $48.2 \%$ of the variance $\left(\mathrm{R}^{2}=0.482, \mathrm{~F}(5,223)=26.02, \mathrm{P}<0.05\right)$. It was found that Employees Behavior significantly predicted Long-term Customer Loyalty $(\beta=.274=, p=0.01)$, as did CRM System Integration $(\beta=.618=, \mathrm{p}=0.000)$.

The econometric model equation:

Long-term Customers' loyalty = 0.274 Employee's Behavior+ 0.618 CRM System Integration.

The interpretations of the significant independent variables: 
- There is a direct impact on employee's behavior and long-term customers' loyalty, and an increasing employee's behavior by 10 units may increase the long-term customers' loyalty by 2.74 units.

- There is a direct impact on CRM system integrations and long-term customers' loyalty, and increasing CRM system integrations by 10 units may increase the long-term customers' loyalty by 6.18 units.

- But there is no impact that means no impact for these predictor variables (service quality, customers' database, solving customer's problems) on the long-term customers' loyalty.

\subsection{Discussion}

The First Hypothesis contended that there is a positive relationship between CRM and Long-term customers' loyalty in the Palestinian banking industry. The scholars' concluded that service quality in-Palestine banking industry plays a significant role in CRM. Solving customer's problems is a significant term which is an indicator for the banks that their customers will not switch to other banks. They also concluded that service quality hasn't the strongest relationship with the formation of long-term customers' loyalty, oppositely, the employee's behavior has a minor relationship with loyalty, less than the influence of service quality.

According to the results, there is a significant impact exists between the selected variables in this model in other words "Indicates that the combination of these variables significantly predicts the dependent variable", $\mathrm{R}^{2}=0.482$ which means the independents variables explain $48.2 \%$ from the variation of dependent variable "long-term customers' loyalty", " $r=0.694$ " shows a positive and strong linear relationship between dependent variable "long-term customers' loyalty" and the predictors (CRM dimensions).

The scholars' results show that only "Employees Behavior" and "CRM System Integration" are significantly contributing in the regression equation. Long et al. (2013) also investigated the influence of various factors of customer relationship management on customers' loyalty. The elements of customer relationship management identified in their thesis were interaction management, customer service quality, employee behavior, and relationship development. From the findings, the scholars' concluded that employee's behavior was the most important construct of customer relationship management in the service industry, and that employee behavior had a significant correlation to customers' loyalty. Employees behavior according to the scholars' point of view will affect the other CRM dimensions, the behavior will affect the other four dimensions and how employees interact with them, if customers were happy to deal with employees, then employees will extract the right information about them that will enrich the customer's database which will be used to enhance the CRM system integration to provide better services that meet their needs, once banks achieve this milestone they will achieve the goal to gain more loyalty from customers.

\section{Conclusion and Recommendations}

The results of this paper showed positive and strong linear relationship between dependent variable "long-term customers' loyalty" and the CRM dimensions, CRM system integration is positively direct effect on long-term customers' loyalty. The paper also determined that there is a direct impact on employee's behavior and long-term customers' loyalty.

The scholars' noted from the results of this paper that bankers need to investigate why male employees more effective in service quality than females in their banks, is that related to that male employees have more attention and training than female employees? In addition, Scholars' recommended that local banks need to improve their capabilities to enhance the level of service quality and employee's behavior and to update their customer's database with the recent technologies, in order to serve and provide customers with required services through gathering the accurate information about them by building a strong relationship between the banks and customers.

\section{References}

Agariya, A. K., \& Singh, D. (2012). crm scale development \& validation in Indian banking sector. Journal of Internet banking and Commerce, 17(1), 1-21.

Amin, S. M., Ahmad, U. N. U., \& Hui, L. S. (2012). Factors contributing to customer loyalty towards telecommunication service provider. Procedia-Social and Behavioral Sciences, 40, 282-286. https://doi.org/10.1016/j.sbspro.2012.03.192

Authority, PMO (n.d.). The Palestine... Retrieved August 07, 2017, from http://www.pma.ps/

Awasthi, P., \& S. Sangle, P. (2013). The importance of value and context for mobile CRM services in banking. Business Process Management Journal, 19(6), 864-891. https://doi.org/10.1108/BPMJ-06-2012-0067 
Beneke, J., Hayworth, C., Hobson, R., \& Mia, Z. (2012). Examining the effect of retail service quality dimensions on customer satisfaction and loyalty: The case of the supermarket shopper. Acta Commercii, 12(1), 27-43. https://doi.org/10.4102/ac.v12i1.129

Burke, J. (2015). Relationship Aspect Marketing: Building Customer Loyalty in the Internet Age. Aberdeen: Silver Lake Pub.

Cohen, J. (1962). The statistical power of abnormal-social psychological research: A review. Journal of Abnormal and Social Psychology, 65(3), 145-153. https://doi.org/10.1037/h0045186

Dowling, G. (2002). Customer Relationship Management: In B2C Markets, Often Less Is More. California Management Review, 44(3), 121-137. https://doi.org/10.2307/41166134

Evanschitzky, H., Ramaseshan, B., Woisetschläger, D. M., Richelsen, V., Blut, M., \& Backhaus, C. (2012). Consequences of customer loyalty to the loyalty program and to the company. Journal of the Academy of Marketing Science, 40(5), 625-638. https://doi.org/10.1007/s11747-011-0272-3

Farquad, M. A. H., Ravi, V., \& Raju, S. B. (2012). Analytical CRM in banking and finance using SVM: a modified active learning-based rule extraction approach. International Journal of Electronic Customer Relationship Management, 6(1), 48-73. https://doi.org/10.1504/IJECRM.2012.046470

Goddard, M. G. J., Raab, G., Ajami, R. A., \& Gargeya, V. B. (2012). Customer relationship management: a global perspective. Farnham: Gower Publishing, Ltd.

Hashem, T. N. (2012). The Impact of Customer Relationship Marketing On Customers Satisfaction for the Banking Industry in Jordan. International Journal of Management Cases, 14(4), 142-153. https://doi.org/10.5848/APBJ.2012.00093

Hassan, M. T., Ahmed, B., Ahmed, S., Habib, U., Riaz, S., Maqbool, N., \& Anwar, A. (2012). Measuring customers loyalty of Islamic banking in Bahawalpur region. International Journal of Learning and Development, 2(2), 101-111. https://doi.org/10.5296/ijld.v2i2.1593

Hollensen, S. (2015). Marketing management: A relationship approach. Upper Saddle River: Pearson Education

Karjaluoto, H., Töllinen, A., Pirttiniemi, J., \& Jayawardhena, C. (2014). Intention to use mobile customer relationship management systems. Industrial Management \& Data Systems, 114(6), 966-978. https://doi.org/10.1108/IMDS-11-2013-0480

Kaur, H., \& Soch, H. (2012, October). Validating Antecedents of Customer Loyalty for Indian Cell Phone Users. Retrieved August 01, 2017, from http://www.vikalpa.com/

Kitapci, O., Taylan Dortyol, I., Yaman, Z., \& Gulmez, M. (2013). The paths from service quality dimensions to customer loyalty: An application on supermarket customers. Management Research Review, 36(3), 239-255. https://doi.org/10.1108/01409171311306391

Krejcie, R. V., \&Morgan, D. W. (1970).Determining Sample Size for Research Activities. Educational and Psychological Measurement. \#30, 607-610 (Sample Size). https://doi.org/10.1177/001316447003000308

Kumar, V., \& Reinartz, W. (2012). Customer relationship management: Concept, strategy, and tools. Berlin: Springer Science \& Business Media. https://doi.org/10.1007/978-3-642-20110-3

Lawfer, M. R. (2014). Why customers come back: How to create lasting customer loyalty. Franklin Lakes, NJ: Career Press.

Long, C. S., Khalafinezhad, R., Ismail, W. K., \& Rasid, S. Z. (2013). Impact of CRM Factors on Customer Satisfaction and Loyalty. Asian Social Science, 9(10). https://doi.org/10.5539/ass.v9n10p247

Lowenstein, M. W. (2014). The customer loyalty pyramid. Westport, Conn: Quorum

Martínez, P., \& Del Bosque, I. R. (2013). CSR and customer loyalty: The roles of trust, customer identification with the company and satisfaction. International Journal of Hospitality Management, 35, 89-99. https://doi.org/10.1016/j.ijhm.2013.05.009

Meadows, M., \& Dibb, S. (2012). Progress in customer relationship management adoption: a cross-sector thesis. Journal of Strategic Marketing, 20(4), 323-344. https://doi.org/10.1080/0965254X.2012.671337

Mosallem, L. (n.d.). Banking sector role in the SMEs development in Palestine. Retrieved October 10, 2017 , from http://www.abp.ps/

Muther, A. (2012). Customer relationship management: Electronic customer care in the new economy. Berlin: 
Springer Science \& Business Media

Nguyen, B., \& Mutum, D. S. (2012a). A review of customer relationship management: successes, advances, pitfalls and futures. Business Process Management Journal, 18(3), 400-419. https://doi.org/10.1108/14637151211232614

Nguyen, B., \& Mutum, D. S. (2012b). Customer relationship management: advances, dark sides, exploitation and unfairness. International Journal of Electronic Customer Relationship Management, 6(1), 1-19. https://doi.org/10.1504/IJECRM.2012.046467

Pan, Y., Sheng, S., \& Xie, F. T. (2012). Antecedents of customer loyalty: An empirical synthesis and reexamination. Journal of Retailing and Consumer Services, 19(1), 150-158. https://doi.org/10.1016/j.jretconser.2011.11.004

Ranade, K. (2012, December 10). Customer Loyalty - What is it? How Can You Measure and Manage It? Retrieved October 02, 2016, from http://www.loyaltyresearch.com/

Rouse, M. (2014, November). Customer relationship management (CRM). Retrieved October 02, 2016, from http://searchcrm.techtarget.com/definition/CRM

Saarijärvi, H., Karjaluoto, H., \& Kuusela, H. (2013a). Extending customer relationship management: from empowering firms to empowering customers. Journal of Systems and Information Technology, 15(2), 140-158. https://doi.org/10.1108/13287261311328877

Saarijärvi, H., Karjaluoto, H., \& Kuusela, H. (2013b). Customer relationship management: the evolving role of customer data. Marketing intelligence \& planning, 31(6), 584-600. https://doi.org/10.1108/MIP-05-2012-0055

Sachs, J. (2013). Customer loyalty. Place of publication not identified: Motivational Press, Inc.

Salawdeh, H. (2009). CRM and Relationship Profitability in Banking. Corporate Technology Solutions. Retrieved August 01, 2017, from https://www.consult-cts.com/why-cts/.../1_75f69442c71061e1ae992492da3d5424

Stein, A. D., Smith, M. F., \& Lancioni, R. A. (2013). The de velopment and diffusion of customer relationship management (CRM) intelligence in business-to-business environments. Industrial Marketing Management, 42(6), 855-861. https://doi.org/10.1016/j.indmarman.2013.06.004

Vella, J., \& Caruana, A. (2012). Encouraging CRM systems usage: a thesis among bank managers. Management Research Review, 35(2), 121-133. https://doi.org/10.1108/01409171211195152

Winer, R. (2001). A framework for customer relationship management. California Management Review, 43(4), 89-105. https://doi.org/10.2307/41166102

\section{Copyrights}

Copyright for this article is retained by the author(s), with first publication rights granted to the journal.

This is an open-access article distributed under the terms and conditions of the Creative Commons Attribution license (http://creativecommons.org/licenses/by/4.0/). 